PressAcademia Procedia

YEAR 2020 VOLUME 12

Istanbul Finance Congress, November 5-6, 2020

\title{
SYSTEMIC RISK OF TUNISIAN FINANCIAL SYSTEM: MEASURING AND PREDICTING FUTURE UNEMPLOYMENT RATE
}

\author{
DOI: 10.17261/Pressacademia.2020.1356 \\ PAP- V.12-2020(20)-p.80-81
}

Dorsaf Azouz Ghachem ${ }^{1}$, Aymen Khamessi ${ }^{2}$

${ }^{1}$ Higher Institute of Management of Tunis, Finance and Accounting, Tunis, Tunisia. ghachemdorsaf.azzouz@isg.u-tunis.tn, ORCID: 0000-0000-9547-2032

${ }^{2}$ Higher Institute of Management of Tunis, Finance and Accounting, Tunis, Tunisia. aymen.khammassi@hotmail.fr, ORCID: 0000-0003-3918-1884

To cite this document

Ghachem, D.A., Khamessi, A., (2020). Systemic risk of Tunisian financial system: measuring and predicting future unemployment rate. PressAcademia Procedia (PAP), V.12, p.80-81.

Permanent link to this document: http://doi.org/10.17261/Pressacademia.2020.1356

Copyright: Published by PressAcademia and limited licensed re-use rights only.

\begin{abstract}
Purpose- The purpose of this study is to measure the systemic risk of the Tunisian financial system around the revolution period by the use of covar method and to test its ability to predict the future unemployment rate in the economy.

Methodology- Our empirical study aims to measure the systemic risk of the Tunisian banking system over the period going from 2008 to 2015. Our study period is marked by the 2011 Tunisian revolution and goes from June 2008 to December 2015. Our research sample consists of the eleven Tunisian listed banks on the Tunisian stock exchange. We calculate monthly bank returns that are calculated as the arithmetic mean of the daily data of the month. We use daily closing pricing data of the eleven listed banks and the stock market index TUNINDEX from 2 January 2008 to 31 December 2015. The variable to explain: Tunindex: the benchmark index of the Tunis Stock Exchange. It is composed of the country's fifty largest capitalizations. It allows an assessment of the market trend. The explanatory variables are the returns of the eleven banks listed on the Tunisian stock exchange. For the measurement of Covar, we approach the bank risk by its historical volatility based on the GARCH (1.1) model developed by Belerselv (1986). We then sum quarterly bank Covars to obtain the Covar of the whole banking system and integrate it into a model, to test empirically the relationship between the calculated "CoVaR and the future unemployment rate in Tunisia during the post-revolution period $(2011-2014)$. We apply the OLS least squares and corrected least squares method. To check for the robustness of obtained results, we then adopt the "VAR" called the Autoregressive Vector (Sims, 1980), which highlights interdependencies between several time series.

Findings- Results show that ATTIJARI BANK is the largest contributor to the TUNINDEX systemic risk before revolution, while BT is the least influent one. Private banks rankings are reversed during post revolution period, against public banks which maintained their ranks. Globally, many private banks that floundered at the bottom of the rankings before revolution rank very high during the following period. Moreover, the top 5 of Tunisian systemic banks after revolution is composed of two public banks and three private ones. Public banks are risky because of the bad governance they suffer due to state intervention. Regards to the most systemic private banks (BT, BIAT et ATB), they seem to be the biggest on the financial place and with the highest performances and outstanding's loans to the economy. Finally, the regressions' results show that the future unemployment rate depends only on the preceding one and not on the systemic risk index (COVAR).

Conclusion- Finally, our research aims to add a broader perspective to establish and ensure compliance with good governance principles within public banks, particularly in terms of independence. Moreover, it encourages for the strengthening of the large private bank prudential supervision, the latters being considered as the most efficient and the most active on markets. Also, our research should be completed by a study of bank's systemic risk determinants in order to better control et prevent any slippages
\end{abstract}

Keywords: Systemic risk, Tunisian banking sector, covar, unemployment rate

JEL Codes: G01, G21, J6

\section{REFERENCES}

Acharya, V., Pedersen, L., Philippon, T., and Richardson, M. (2017). Measuring Systemic Risk, The Review of Financial Studies, Vol. 30, Issue 1 , January 2017 , p. 2-47 
Adrian, T., and Brunnermeier, M.K., (2011). Covar, NBER Working Paper, N w17454.

Aglıetta, M., (2003), Le Risque Systémique Dans La Finance Libéralisée, Revue D'économie Financière, 70 ,p. 33-50.

Allen, L., Bali, T. G., and Tang, Y. (2012). Does Systemic Risk in The Financial Sector Predict Future Economic Downturs?, Review of Financial Studies, Vol. 25, Issue 10, p.3000-3036.

Banulescu, G.-D., Dumitrescu, E-I. (2014). Which Are the Sifis? A Component Expected Shortfall Approach to Systemic Risk. Journal of Banking and Finance, p.1-14.

Brownlees, C. and R.F., Engle, (2017). Srisk: A Conditional Capital Shortfall Measure of Systemic Risk, Review of Financial Studies, Society for Financial Studies, Vol. 30, Issue 1, p.48-79.

Central Bank of Tunisia, (2015). Annual Report, www.Bct.Gov.Tn/Bct/Siteprod/Documents/Ra 2015 Fr.Pdf

Central Bank of Tunisia, (2018). Annual Report, On Banking Supervision, www.Bct.Gov.Tn/Bct/Siteprod/Documents/Sup Bc Fr.Pdf

De Bandt, O., \& Hartmann, P. (2000). Systemic Risk A Survey. European Central Bank Working Paper Series, No.35. Frankfurt: European Central Bank.

Fisher, R.J., (1993), Social Desirability Bias and the Validity of Indirect Questioning, Journal of Consumer Research, Volume 20, Issue 2, p.303315.

Hmissi, B., A. Bejaoui and W. Snoussi, (2017), On Identifying the Domestic Systemically Important Banks: The Case of Tunisia, Research in International Business and Finance, 42, p.1343 - 1354.

Jorion, P., (2007), Value At Risk : The New Benchmark for Managing Financial Risk, Financial Markets and Portfolio Management, Vol. 21, Issue 3, p.397-398.

Khiari, W. and J. Nachnouchi, (2017), Bank's Systemic Risk in the Tunisian Context: Measures and Determinants, Research in International Business and Finance, Elsevier, Vol 45, p. 620-631.

Khiari, W. and S. Ben Sassi, (2019), On Identifying the Systemically Important Tunisian Banks: An Empirical Approach Based on the $\Delta$ covar Measures, Risks, 7, 122; Doi:10.3390/Risks7040122.

Manganelli, Simone and Engle, Robert F., Value at Risk Models in Finance (August 2001). ECB Working Paper No. 75, Available at SSRN: https://ssrn.com/abstract $=356220$

Mishkin, F., (2005), The Inflation Targeting Debate, National Bureau of Economic Research, School of Business, Columbia University.

Sarin, N., and L. H. Summers, (2016), Have Big Banks Gotten Safer? Brookings Papers on Economic Activity, Bpea Conference Draft.

Sims, C. A., (1980), Macroeconomics and Reality, Econometrica, Vol. 48 (1), p. 1-48. 